\title{
Two different trichoscopic patterns of mid-frontal scalp in patients with frontal fibrosing alopecia and clinical features of androgenetic alopecia
}

\author{
Dwa różne wzory trichoskopowe okolicy czołowej u pacjentek z łysieniem \\ czołowym bliznowaciejącym i klinicznymi objawami łysienia androgenowego
}

Adriana Rakowska, Anna Waśkiel, Mariusz Sikora, Małgorzata Olszewska, Lidia Rudnicka

Department of Dermatology, Medical University of Warsaw, Warsaw, Poland

Przegl Dermatol 2017, 104, 9-15

DOI: https://doi.org/l0.5। |4/dr.2017.66217

KEY WORDS:

frontal fibrosing alopecia, androgenetic alopecia, trichoscopy, hair loss, cicatricial alopecia.

SŁOWA KLUCZOWE:

łysienie czołowe bliznowaciejące, łysienie androgenowe, trichoskopia, łysienie, łysienie bliznowaciejące.

ADDRESS FOR CORRESPONDENCE:

Adriana Rakowska MD, PhD

Department of Dermatology

Medical University of Warsaw

82a Koszykowa St

00-005 Warsaw, Poland

Phone: +48225021324

E-mail: adriana.rakowska@gmail. com

\section{ABSTRACT}

Introduction. Frontal fibrosing alopecia is a primary lymphocytic cicatricial alopecia with progressive frontotemporal hairline recession. In some cases, hair loss in the mid-frontal scalp, similar to female pattern hair loss, may be observed.

Objective. Assessment of the trichoscopic pattern of mid-frontal scalp hair loss in patients diagnosed with frontal fibrosing alopecia.

Material and methods. The retrospective analysis included 31 women diagnosed with frontal fibrosing alopecia and hair loss in the mid-frontal scalp and 36 women diagnosed with female pattern hair loss.

Results. In patients with frontal fibrosing alopecia two different trichoscopic patterns in the mid-frontal scalp were identified. In $68 \%$ of patients $(21 / 31)$ we observed a diffuse fibrotic pattern. It was characterized by irregular arrangement of follicular units with small areas with loss of follicular units, an increased percentage of follicular units with one hair and a decreased percentage of follicular units with three hairs, normal hair shaft thickness and presence of mild perifollicular scaling. The androgenetic alopecia pattern was present in $32 \%$ of patients $(10 / 31)$. It was characterized by hair shaft thickness diversity $(20 \%$ or more), a percentage of vellus hairs higher than $10 \%$, presence of yellow dots, an increased percentage of follicular units with one hair and a decreased percentage of follicular units with three hairs.

Conclusions. In patients with frontal fibrosing alopecia and coexisting mid-frontal scalp hair loss, we identified two different patterns of this area in trichoscopy: the diffuse fibrotic pattern (more common) and the androgenetic alopecia pattern. This observation may have therapeutic and prognostic implications.

\section{STRESZCZENIE}

Wprowadzenie. Łysienie czołowe bliznowaciejące jest pierwotnym, limfocytarnym łysieniem bliznowaciejącym, w którym dochodzi do przesuwania się linii czołowo-skroniowej owłosienia ku tyłowi. U dużego odsetka pacjentek z rozpoznanym łysieniem czołowym bliznowaciejącym występuje także przerzedzenie włosów w okolicy czołowej, przypominające klinicznie łysienie androgenowe. 
Cel pracy. Ustalenie trichoskopowego wzoru łysienia w okolicy androgenozależnej u pacjentek z rozpoznanym łysieniem czołowym bliznowaciejącym.

Materiał i metodyka. Do retrospektywnej analizy (oceny obrazów trichoskopowych) włączono 31 kobiet z łysieniem czołowym bliznowaciejącym i 36 kobiet z łysieniem androgenowym.

Wyniki. Ustalono dwa różne wzory trichoskopowe. U 68\% (21/31) pacjentek stwierdzono wzór rozlanego łysienia bliznowaciejącego charakteryzującego się nieregularnym rozkładem jednostek włosowych, małymi obszarami pozbawionymi jednostek włosowych, brakiem trichoskopowych objawów miniaturyzacji mieszków włosowych, zmniejszonym odsetkiem jednostek włosowych z trzema łodygami, zwiększonym odsetkiem jednostek włosowych $\mathrm{z}$ jedną łodygą oraz obecnością okołomieszkowego złuszczania. U 32\% (10/31) pacjentek wykazano wzór łysienia androgenowego, który charakteryzował się obecnością powyżej 10\% włosów meszkowych, heterogenicznością grubości łodyg włosów (> 20\%), obecnością żółtych kropek, zwiększonym odsetkiem jednostek włosowych $\mathrm{z}$ jedną łodygą oraz zmniejszonym odsetkiem jednostek włosowych z trzema łodygami.

Wnioski. W badaniu trichoskopowym okolicy androgenozależnej u pacjentek $\mathrm{z}$ rozpoznanym łysieniem czołowym bliznowaciejącym oraz przerzedzeniem włosów w okolicy czołowej stwierdzono dwa różne wzory trichoskopowe: wzór rozlanego łysienia bliznowaciejącego (występujący częściej) oraz wzór łysienia androgenowego. Przedstawione wyniki mogą w przyszłości znaleźć zastosowanie w ocenie rokowania i optymalizacji leczenia łysienia czołowego bliznowaciejącego.

\section{INTRODUCTION}

Frontal fibrosing alopecia (FFA) is a primary lymphocytic cicatricial alopecia with progressive frontotemporal hairline recession. It was first described by Kossard in 1994 [1]. Histological examination of the affected area of the scalp reveals perifollicular lymphocytic infiltrate, reduction in the number of hair follicles and replacement by fibrous tracts [2]. Currently FFA is considered to be a variant of lichen planopilaris (LPP) with the lymphocytic infiltrate and fibrosis affecting selectively the vellus and the intermediate hair follicles of the frontotemporal margin [3].

The pathogenesis of FFA is still unknown, but involvement of the autoimmune reaction [4] and hormonal factors $[3,5]$ have been discussed. It is hypothesized that an estrogen and androgen imbalance can trigger the inflammatory scarring reaction in FFA [6]. The role of hormones in FFA pathogenesis is supported by the higher frequency of the disease in postmenopausal women and improvement of the disease course after antiandrogenic treatment with finasteride or dutasteride [6]. The disease predominantly occurs in postmenopausal women, but men and premenopausal women may also be affected [6].
The FFA is characterized by slowly progressive and symmetrical recession of the frontotemporal hairline [2]. Eyebrow loss is observed in $50-75 \%$ of patients $[7,8]$. Facial papules, nail involvement and diffuse hair loss at other sites of the body have been described less frequently [9-11].

In our observations the majority of patients diagnosed with FFA complain not only of recession of the frontotemporal hairline but also mid-frontal scalp hair loss. Clinical examination may suggest that FFA frequently coexists with female pattern hair loss (FPHL).

\section{OBJECTIVE}

The aim of the study was to assess the trichoscopic pattern of mid-scalp hair loss in patients diagnosed with FFA and coexisting clinical features of FPHL.

\section{MATERIAL AND METHODS}

This retrospective analysis included 31 women diagnosed with FFA associated with mid-frontal scalp hair loss and 36 women diagnosed with FPHL. The FFA patients with mid-frontal effluvium were select- 
ed from 59 patients diagnosed with FFA (patients with no features of mid-scalp hair loss and with focal alopecia caused by LPP were excluded).

All of the patients were examined in our outpatient department between 2012 and 2017. The group was adjusted for age and number of patients. The mean age of women in the FFA group was 52 years (range: $38-68$ ) and 46 years in the FPHL group (range: 35-59).

The diagnosis of FFA and FPHL was established on the basis of a detailed medical history, clinical examination and trichoscopy. The severity of hair loss was assessed according to the Ludwig scale. In the FFA group: Ludwig 1: 5 (16\%) patients, Ludwig 2: $23(74 \%)$ patients, Ludwig 3: $3(10 \%)$ patients. In the FPHL group: Ludwig 1: 8 (22\%) patients, Lud- wig 2: 22 (61\%) patients, Ludwig 3: $6(17 \%)$ patients (Figure 1).

In every case, as a routine procedure, trichoscopy using Fotofinder II (10 images at 20- and 70-fold magnification) was performed. The trichoscopy images were assessed according to the scheme presented in Table 1.

\section{Statistical analysis}

Statistical analysis of the data was conducted using Statistica software, version 12.0 (StatSoft, Krakow, Poland). Comparisons between parameters were evaluated by one-way repeated-measures analysis of variance (ANOVA), followed by post-hoc analysis using Dunnett's test. Statistical significance was considered for $p$-values less than 0.05 .
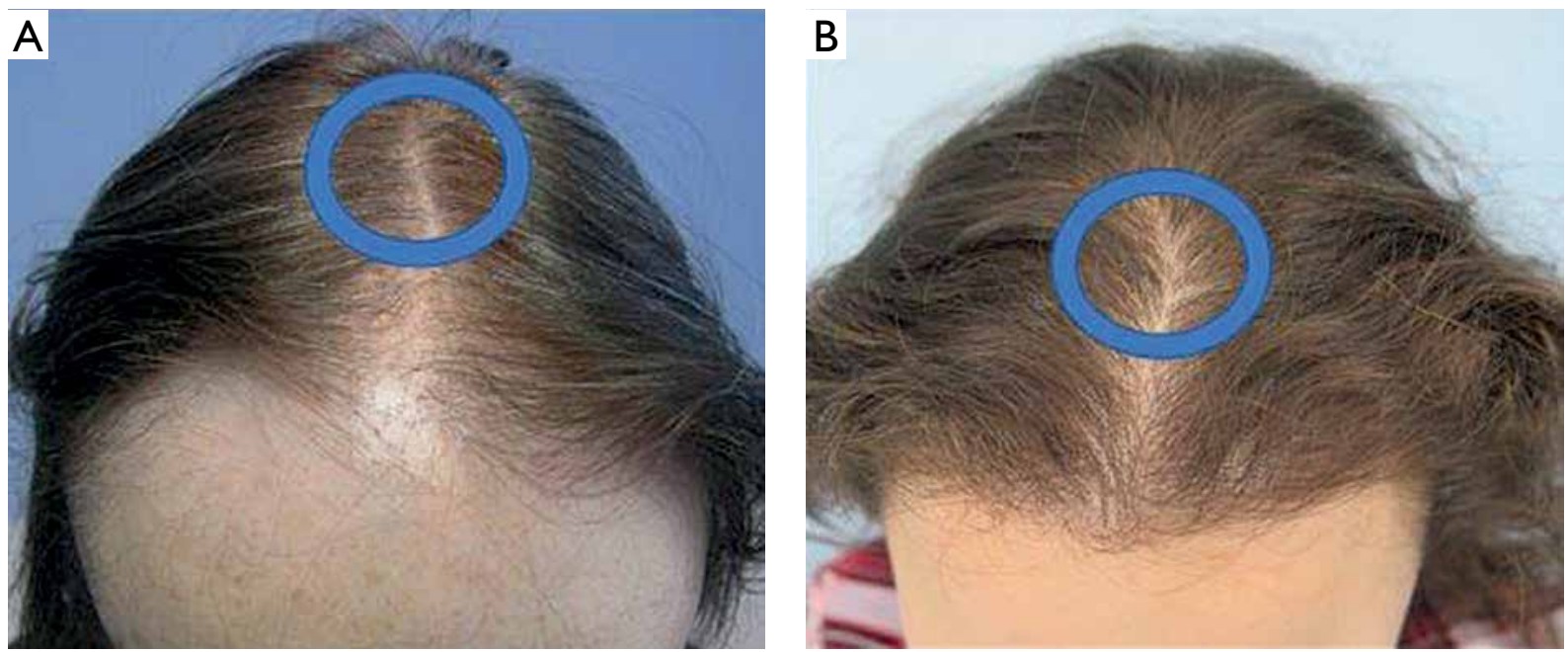

Figure I. Similar clinical presentation of mid-frontal scalp hair loss in patients diagnosed with: A) frontal fibrosing alopecia - typical frontotemporal hairline recession may be observed, B) female pattern hair loss. The exact place of trichoscopy examination is marked by a blue circle $(A, B)$

Rycina I. Podobny obraz kliniczny przerzedzenia włosów w okolicy czołowej u pacjentek z rozpoznanym: A) tysieniem czołowym bliznowaciejq̨cym - na rycinie można zaobserwować typowe przesunięcie linii czołowo-skroniowej, B) łysieniem androgenowym. Miejsce wykonania trichoskopii oznaczono niebieskim okręgiem (A, B)

Table I. Scheme of the trichoscopy image evaluation in the present study

Tabela I. Protokół przeprowadzanego badania trichoskopowego

\begin{tabular}{|c|c|}
\hline Parameter & Method of evaluation \\
\hline \multirow[t]{2}{*}{ Distribution of hair thickness } & Variability in the hair shaft diameter of more or less than $20 \%$ of hair shafts \\
\hline & Percent age of vellus hair (higher or lower than 10\%) \\
\hline \multirow[t]{3}{*}{ Pilosebaceous units } & Percentage of single-hair units (at 20-fold magnification) \\
\hline & Percentage of double-hair units (at 20-fold magnification) \\
\hline & Percentage of triple-hair units (at 20-fold magnification) \\
\hline Yellow dots & Number of yellow dots per field of vision calculated in four fields of vision at 70 -fold magnification \\
\hline $\begin{array}{l}\text { Perifollicular yellow discoloration } \\
\text { (hyperpigmentation) }\end{array}$ & $\begin{array}{l}\text { Percentage of follicular ostia with perifollicular yellow discoloration calculated at 20-fold } \\
\text { magnification }\end{array}$ \\
\hline \multirow[t]{2}{*}{ Other } & Loss of single follicular units \\
\hline & Presence of mild perifollicular scaling \\
\hline
\end{tabular}




\section{RESULTS}

In $52 \%(16 / 31)$ of patients with FFA disturbance in the normal arrangement of follicular units was observed as small areas with loss of follicular units. Yellow dots, corresponding to the kenogen phase in the hair cycle, were more commonly found in the FPHL group compared to the FFA group (83\%, $30 / 36$ and $45 \%, 14 / 31$, respectively) $(p<0.001)$. Hair shaft thickness diversity was more often observed in the FPHL group than in the FFA group (97\%, 35/36 and $32 \%, 10 / 31$, respectively) $(p<0.001)$. A percentage of vellus hairs higher than $10 \%$ was observed more commonly in FPHL patients than in the FFA group (78\%, 28/36 and 26\%,8/31, respectively) ( $p<$ $0.001)$. In FFA patients compared to FPHL patients a higher percentage of follicular units with one hair (30\% and $15 \%$, respectively) $(p<0.05)$ and a lower percentage of follicular units with three hairs $(10 \%$ and $30 \%$, respectively) $(p<0.05)$ were observed. Incidence of peripilar sign was comparable in the two groups. Mild perifollicular scaling was present in $42 \%(13 / 31)$ of patients with FFA and was not seen in the FPHL group $(p<0.001)$. Detailed results are presented in Table 2.

In the FFA group during mid-frontal scalp examination two different trichoscopic patterns of hair loss were identified. In $68 \%(21 / 31)$ of patients the diffuse fibrotic pattern was observed. It was characterized by disturbance in normal follicular arrangement with small areas lacking follicular units and yellow dots, predominance of follicular units with one or two hairs, no features of follicular miniaturization (percentage of vellus hairs higher less 10\%, no signs of hair shaft thickness diversity) and presence of mild perifollicular scaling. The androgenetic alopecia pattern was observed in $32 \%$ (10/31) of patients. It was characterized by hair shaft thickness diversity ( $20 \%$ or more), vellus hairs in a percentage higher than $10 \%$, presence of yellow dots, an increased percentage of follicular units with one hair and a decreased percentage of follicular units with three hairs. Figure 2 presents trichoscopic images representative for FPHL and FFA (two different patterns). Comparison between trichoscopic patterns of the mid-frontal scalp area in FFA is presented in Table 3.

\section{DISCUSSION}

Trichoscopy findings of the frontotemporal line in patients with FFA include minor perifollicular scaling, areas with a lack of follicular units (these

Table 2. Features observed in mid-scalp trichoscopy in patients diagnosed with frontal fibrosing alopecia and female pattern hair loss

Tabela 2. Cechy trichoskopowe okolicy czołowej u pacjentek z rozpoznanym tysieniem czołowym bliznowaciejącym oraz tysieniem androgenowym

\begin{tabular}{|c|c|c|c|}
\hline Trichoscopic feature & FFA & FPHL & $P$-value \\
\hline Diversity of hair shaft diameter $>20 \%$ & $32 \%(\mid 0 / 31)$ & $97 \%(35 / 36)$ & $<0.001$ \\
\hline Vellus hairs $>10 \%$ & $26 \%(8 / 3 I)$ & $78 \%(28 / 36)$ & $<0.001$ \\
\hline Yellow dots (more than 4 in 4 fields of vision) & $45 \%(|4 / 3|)$ & $83 \%(30 / 36)$ & $<0.001$ \\
\hline Peripilar sign & $10 \%(3 / 3 \mid)$ & $14 \%(5 / 36)$ & \\
\hline Small areas with loss of follicular units & $52 \%(|6 / 3|)$ & 0 & $<0.001$ \\
\hline Mild perifollicular scaling & $42 \%(|3 / 3|)$ & 0 & $<0.001$ \\
\hline Mean \% of triple-follicular units & $10 \%(0-40)$ & $30 \%(0-50)$ & $<0.05$ \\
\hline Mean \% of single-follicular units & $30 \%(20-60)$ & $15 \%(5-40)$ & $<0.05$ \\
\hline
\end{tabular}

Table 3. Comparison of two trichoscopic patterns (androgenetic alopecia pattern and diffuse fibrotic pattern) of mid-scalp in FFA patients Tabela 3. Porównanie dwóch wzorów trichoskopowych (wzór tysienia androgenowego i wzór rozlanego łysienia bliznowaciejącego) okolicy czołowej u pacjentek z rozpoznanym tysieniem czołowym bliznowaciejącym

\begin{tabular}{lccc} 
Trichoscopic feature & Diffuse fibrotic pattern & Androgenetic pattern & $P$-value \\
Diversity of hair shaft diameter $>20 \%$ & $9.5 \%(2 / 21)$ & $80 \%(8 / 10)$ & $<0.00$ I \\
\hline Vellus hairs $>10 \%$ & $19 \%(4 / 21)$ & $90 \%(9 / 10)$ & $<0.00$ I \\
\hline Yellow dots (more than 4 in 4 fields of vision) & $14 \%(3 / 21)$ & $100 \%(10 / 10)$ & $<0.00$ I \\
\hline Small areas with loss of follicular units & $100 \%(21 / 21)$ & $0 \%(0 / 10)$ & $<0.00$ I \\
\hline Mild perifollicular scaling & $57 \%(12 / 21)$ & $10 \%(1 / 10)$ & $<0.00$ I \\
\hline Mean \% of triple-follicular units & $10 \%(0-30)$ & $10 \%(0-50)$ & \\
\hline Mean \% of single-follicular units & $30 \%(20-60)$ & $30 \%(20-50)$ & \\
\hline
\end{tabular}



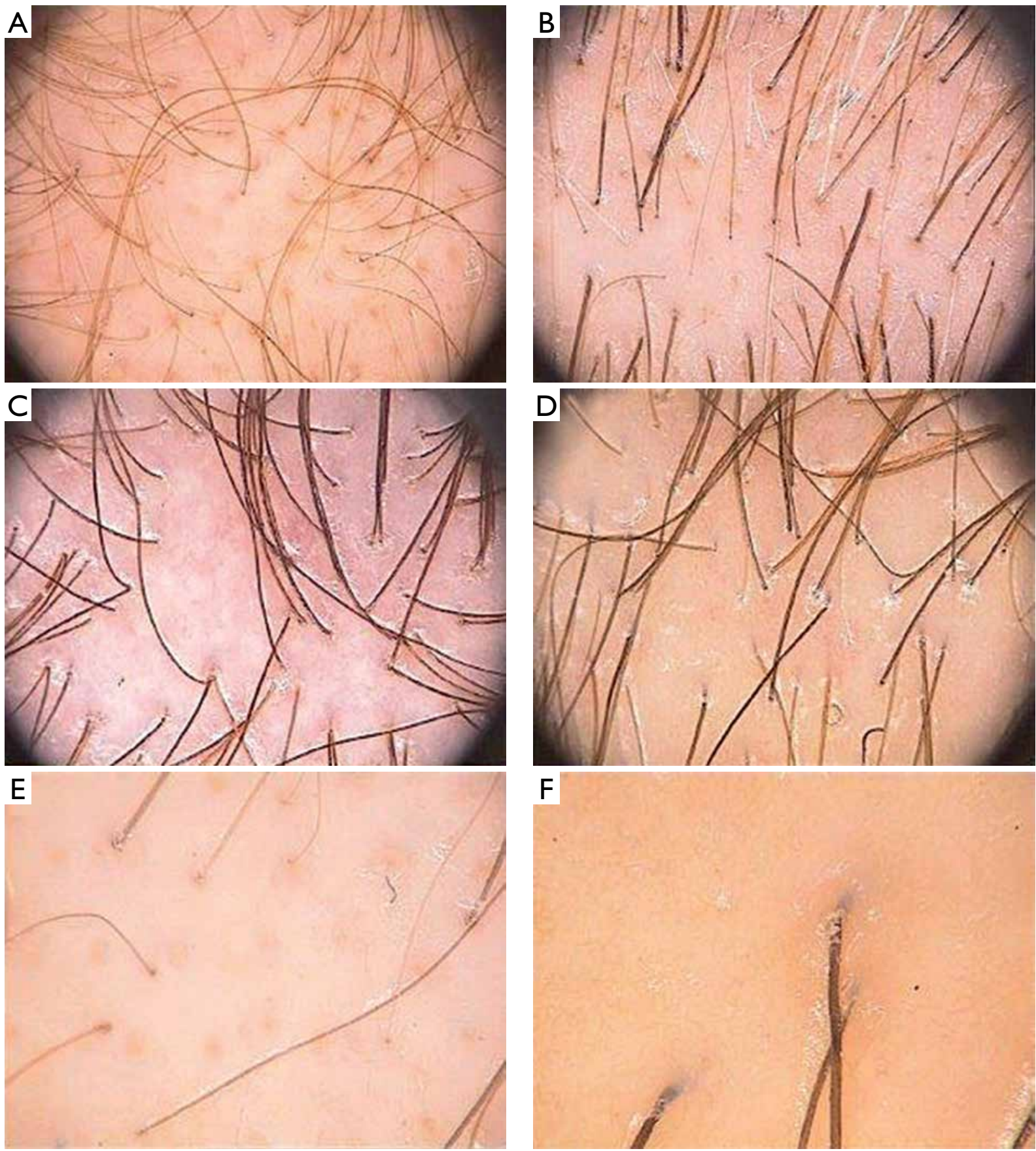

Figure 2. Trichoscopy images taken from mid-frontal scalp in patients with frontal fibrosing alopecia (B-D, F) and female pattern hair loss $(A, E)$. A - female pattern hair loss: hair shaft thickness diversity, vellous hairs, yellow dots, 30\% of follicular units with one hair and $10 \%$ of follicular units with three hairs $(20 \times), \mathrm{B}$ - androgenetic alopecia pattern: hair shaft thickness diversity, presence of vellous hairs, yellow dots, $30 \%$ of follicular units with one hair and 10\% of follicular units with three hairs $(20 \times), \mathrm{C}$ - diffuse fibrotic pattern: irregular arrangement of follicular units with loss of follicular units, normal hair shaft thickness, no vellous hairs, an increased percentage of follicular units with one hair and a decreased percentage of follicular units with three hairs $(20 \times)$, D - diffuse fibrotic pattern: small areas with loss of follicular units, normal hair shaft thickness, mild perifollicular scaling, no presence of vellus hairs (20X), E - female pattern hair loss: hair shaft thickness diversity, vellus hairs, yellow dots and follicular units with one hair $(70 \times), F$ - diffuse fibrotic pattern: normal hair shaft thickness, follicular units with only one hair and small areas lacking follicular units $(70 \times)$

Rycina 2. Obrazy trichoskopowe okolicy czołowej pacjentek z łysieniem czołowym bliznowaciejacym (B-D, F) oraz łysieniem androgenowym $(A, E)$. A - tysienie androgenowe: heterogeniczność grubości todyg, włosy meszkowe, żótte kropki, 30\% jednostek włosowych z jedna todyga, $10 \%$ jednostek włosowych z trzema łodygami (20X), B - wzór łysienia androgenowego: heterogeniczność grubości todyg, obecne włosy meszkowe, żótte kropki, 30\% jednostek włosowych z jednq todyga oraz 10\% jednostek włosowych z trzema todygami (20×), C - wzór rozlanego łysienia bliznowaciejq̨cego: zaburzenie układu jednostek włosowych, małe obszary pozbawione jednostek włosowych, prawidłowa grubość łodyg, brak włosów meszkowych (20×), D - wzór rozlanego łysienia bliznowaciejacego: małe obszary pozbawione jednostek włosowych, prawidłowa grubość łodyg, złuszczanie okołomieszkowe, brak włosów meszkowych (20), E- tysienie androgenowe: heterogeniczność grubości todyg, włosy meszkowe, żótte kropki, jednostki włosowe z jedna todygq (70×), F - wzór rozlanego łysienia bliznowaciejq̨cego: prawidłowa grubość łodyg, jednostki włosowe z jedną łodyga oraz małe obszary pozbawione jednostek włosowych (70×) 
features are characteristic for LPP) and presence of lonely hairs [12-14]. Perifollicular erythema was described as a direct marker of FFA activity [13].

According to our results, in patients with FFA, mid-frontal scalp hair loss with clinical presentation similar to FPHL is observed (53\% of FFA patients in our study). To the best of our knowledge, this is the first study evaluating trichoscopy of the mid-frontal scalp in patients diagnosed with FFA. In our study two different trichoscopic patterns were identified in this area of the scalp: the diffuse fibrotic pattern and the androgenetic alopecia pattern.

The FPHL is a common non-scarring alopecia with widening of the midline hair-part at the crown. Trichoscopy abnormalities in FPHL of the mid-frontal scalp include: more than $10 \%$ thin hairs (below $0.03 \mathrm{~mm}$ ), hair shaft thickness diversity $20 \%$ or more, more than four yellow dots in four images (70-fold magnification), lower average hair thickness in the frontal area than in the occiput, an increased number of follicular units with one hair, a decreased number of follicular units with three hairs and presence of peripilar sign [15-17]. Androgenetic alopecia pattern in the mid-frontal scalp was only observed in $32 \%$ of FFA patients in this study. It was characterized by vellus hairs in a percentage higher than $10 \%$, hair shaft thickness diversity (more than 20\%), yellow dots, an increased percentage of follicular units with one hair and a decreased percentage of follicular units with three hairs.

Fibrosing alopecia in a pattern distribution classified as a subtype of LPP is a form of progressive scarring alopecia [18]. In histopathology miniaturization of hair follicles and lichenoid type of follicular inflammation may be found. There is no detailed information about trichoscopy in fibrosing alopecia in a pattern distribution: in one case report description of perifollicular erythema, small areas with loss of follicular units and perifollicular scaling in the midscalp area were observed [18].

In our study in $68 \%$ of patients with FFA a diffuse fibrotic pattern in the mid-frontal scalp was observed. In contrast to female pattern hair loss, it may be considered as an effect of minimal fibrosis that mainly involves miniaturized hairs (intermediate and vellus hairs) and results in loss of follicular units and vellus hairs. It can be suspected that in some patients with FFA the lymphocytic inflammatory infiltrate affects intermediate and vellus hair follicles in the whole androgen-dependent scalp, not only at the border of the frontal area. According to this observation, irregular arrangement of follicular units with areas lacking hair shafts and vellus hairs as well as normal hair shaft thickness may be noted.

These two different trichoscopic patterns may affect the choice of therapy and prognosis for hair re- growth. It is considered that patients with the androgenic alopecia pattern in the mid-frontal scalp may improve with antiandrogenic treatment, whereas in patients with the diffuse fibrotic pattern only a reduction of disease activity may be achieved.

\section{CONCLUSIONS}

We suggest that mid-frontal scalp hair loss in patients with frontal fibrosing alopecia is more commonly diffuse fibrosing alopecia than androgenetic alopecia. Distinguishing the two trichoscopic patterns established in this study may be of prognostic value and have therapeutic implications.

\section{Conflict of interest}

The authors declare no conflict of interest.

\section{References}

1. Kossard S.: Postmenopausal frontal fibrosing alopecia. Scarring alopecia in a pattern distribution. Arch Dermatol 1994, 130, 770-774.

2. Kossard S., Lee M.S., Wilkinson B.: Postmenopausal frontal fibrosing alopecia: a frontal variant of lichen planopilaris. J Am Acad Dermatol 1997, 36, 59-66.

3. Tosti A., Piraccini B.M., Iorizzo M., Misciali C.: Frontal fibrosing alopecia in postmenopausal women. J Am Acad Dermatol 2005, 52, 55-60.

4. Vaisse V., Matard B., Assouly P., Jouannique C., Reygagne P.: Postmenopausal frontal fibrosing alopecia: 20 cases. Ann Dermatol Venereol 2003, 130, 607-610.

5. Gaspar N.K.: DHEA and frontal fibrosing alopecia: molecular and physiopathological mechanisms. An Bras Dermatol 2016, 91, 776-780.

6. Vano-Galvan S., Molina-Ruiz A.M., Serrano-Falcon C., Arias-Santiago S., Rodrigues-Barata A.R., Garnacho-Saucedo G., et al.: Frontal fibrosing alopecia: a multicenter review of 355 patients. J Am Acad Dermatol 2014, 70, 670-678.

7. Moreno-Ramirez D., Camacho Martinez F.: Frontal fibrosing alopecia: a survey in 16 patients. J Eur Acad Dermatol Venereol 2005, 19, 700-705.

8. Samrao A., Chew A.L., Price V.: Frontal fibrosing alopecia: a clinical review of 36 patients. Br J Dermatol 2010, 163, 1296-1300.

9. Donati A., Molina L., Doche I., Valente N.S., Romiti R.: Facial papules in frontal fibrosing alopecia: evidence of vellus follicle involvement. Arch Dermatol 2011, 147, 1424-1427.

10. Tan K.T., Messenger A.G.: Frontal fibrosing alopecia: clinical presentations and prognosis. Br J Dermatol 2009, 160, 75-79.

11. Macpherson M., Hohendorf-Ansari P., Trueb R.M.: Nail involvement in frontal fibrosing alopecia. Int J Trichology 2015, 7, 64-66.

12. Rudnicka L., Olszewska M., Rakowska A., Slowinska M.: Trichoscopy update 2011. J Dermatol Case Rep 2011, 5, 82-88.

13. Toledo-Pastrana T., Hernandez M.J., Camacho Martinez F.M.: Perifollicular erythema as a trichoscopy sign of progression in frontal fibrosing alopecia. Int J Trichology 2013, 5, 151-153.

14. Rakowska A., Slowinska M., Kowalska-Oledzka E., Warszawik O., Czuwara J., Olszewska M., et al.: Trichoscopy of cicatricial alopecia. J Drugs Dermatol 2012, 11, 753-758. 
15. Harries M., Tosti A., Bergfeld W., Blume-Peytavi U., Shapiro J., Lutz G., et al.: Towards a consensus on how to diagnose and quantify female pattern hair loss - The 'Female Pattern Hair Loss Severity Index (FPHL-SI)'. J Eur Acad Dermatol Venereol 2016, 30, 667-676.

16. Rakowska A.: Trichoscopy (hair and scalp videodermoscopy) in the healthy female. Method standardization and norms for measurable parameters. J Dermatol Case Rep $2009,3,14-19$

Received: 8 XII 2016

Accepted: 20 II 2017
17. Rakowska A., Slowinska M., Kowalska-Oledzka E., Olszewska M., Rudnicka L.: Dermoscopy in female androgenic alopecia: method standardization and diagnostic criteria. Int J Trichology 2009, 1, 123-130.

18. Ramanauskaite A., Trueb R.M.: Facial papules in fibrosing alopecia in a pattern distribution (cicatricial pattern hair loss). Int J Trichology 2015, 7, 119-122. 